\title{
Toward a Model of Growth Stages for Knowledge Management Technology in Law Firms
}

\author{
Petter Gottschalk \\ Norwegian School of Management, Sandvika, Norway
}

petter.gottschalk@bi.no

Abstract

Knowledge management was introduced to law firms to help create, share, and use knowledge more effectively. Information technology can play an important role in successful knowledge management initiatives. In this paper, information technology support for knowledge management is linked to stages of growth. A model of growth stages is proposed consisting of four stages. The first stage is end-user tools that are made available to knowledge workers, the second stage is information about who knows, the third stage is information from knowledge workers, and the final stage is information systems solving knowledge problems. The model can be used to empirically assess the growth stage of law firms as well as indicate future evolution of law firms in the area of knowledge management technology.

Keywords: knowledge management, information technology, stages of growth model, law firms.

\section{Introduction}

Knowledge management has long been considered an important approach for law firms in gaining competitive advantage. The role of information technology in knowledge management is increasing, and law firms are applying different kinds of technology to support knowledge management. This article proposes a model of growth stages for knowledge management technology in law firms. The model is useful to understand the current stage in a specific law firm, and it is useful to develop strategies for future use of information technology in a law firm.

The article is organized as follows. First, law firms are defined in terms of knowledge organizations. Then, knowledge management is presented in terms of the knowledge-based view of the firm. In the third section, knowledge categories in law firms are presented. The role of IT is then discussed before stages of growth models are presented. Finally, the proposed knowledge management technology (KMT) stage model is presented and applied to law firms.

\section{Law Firms}

A law firm can be understood as a social community specializing in the speed and efficiency in the creation and

\footnotetext{
Material published as part of this journal, either on-line or in print, is copyrighted by the publisher of Informing Science. Permission to make digital or paper copy of part or all of these works for personal or classroom use is granted without fee provided that the copies are not made or distributed for profit or commercial advantage AND that copies 1) bear this notice in full and 2) give the full citation on the first page. It is permissible to abstract these works so long as credit is given. To copy in all other cases or to republish or to post on a server or to redistribute to lists requires specific permission and payment of a fee. Contact Editor@inform.nu to request redistribution permission.
}

transfer of legal knowledge (Nahapiet and Ghoshal, 1998). Many law firms represent large corporate enterprises, organizations, or entrepreneurs with a need for continuous and specialized legal services that can only be supplied by a team of lawyers. The client is a customer of the firm, rather than just the customer of a particular lawyer. According to Galanter and Palay (1991), relationships with clients tend to be enduring. Such repeat clients are able to gain benefits from the continuity and economies of scale and scope enjoyed by the firm.

Lawyers can be defined as knowledge workers. They are professionals who have gained knowledge through formal education (explicit) and through learning on the job (tacit). Often there is some variation in the quality of their education and learning. The value of professionals' education tends to hold throughout their careers. For example, lawyers in Norway are asked whether they got the good grade of 'laud' (now A), even 30 years after graduation. Professionals' prestige (which is based partly on the institutions from which they obtained their education) is a valuable organizational resource because of the elite social network that provides access to valuable external resources for the firm (Hitt et al., 2001).

After completing their advanced educational requirements, most professionals enter their careers as associates in law. In this role, they continue to learn and thus, they gain significant tacit knowledge through learning-by-doing. Therefore, they largely bring explicit knowledge derived from formal education into their firms and build tacit knowledge through experience (Hitt et al., 2001).

Most professional service firms use a partnership form of organization. In such a framework, those who are highly effective in using and applying knowledge are eventually 
rewarded with partner status, and thus own stakes in a firm. On their road to partnership, these professionals acquire considerable knowledge, much of which is tacit. Thus, by the time professionals achieve partnership, they have built human capital in the form of individual skills (Hitt et al., 2001).

Lawyers work in law firms, and law firms belong to the legal industry. According to Becker et al. (2001), the legal industry will change rapidly because of three important trends. First, global companies increasingly seek out law firms that can provide consistent support at all business locations and integrated cross-border assistance for significant mergers and acquisitions, as well as capital-market transactions. Second, client loyalty is decreasing as companies increasingly base purchases of legal services on a more objective assessment of their value, defined as benefits net of price. Finally, new competitors have entered the market, such as accounting firms and Internet-based legal services firms.

Montana (2000) is not convinced that law firms will change, arguing that law stands out as an anachronism in the age of knowledge management. Law is entirely manmade; there are no hidden physical principles. A person researching some question of law ought to be able to quickly and easily derive an answer with certainty. According to Montana (2000), nothing is further from the truth. The entire body of law is an accumulated historical knowledge without organization. Law is a conservative calling steeped in its own traditions. Montana (2000) predicts that little will happen because of the following obstacles: expectations, cost, training, and vested interests.

Therefore, both Becker et al. (2001) and Mountain (2001) believe that law firms will have to change. Mountain (2001) has addressed the question why law firms ought to invest in online legal services when studies to date show that there is no correlation between law firm technology and profitability. He argues that legal web advisors are a disruptive technology that law firm competitors, such as accounting firms, dot-coms, and corporate clients, are beginning to harness to erode law firm margins.

Many experts in the field seem to agree that the competitive strength of a law firm comes from knowledge. Knowledge is a renewable, reusable, and accumulating resource of value to the firm when applied in the production of legal services. Furthermore, all authors seem to agree that knowledge management can be improved in law firms, and that information technology can be an enabler of knowledge management improvement in law firms.

\section{Knowledge Management}

A new perspective on knowledge in organizations is being created. Organizations are viewed as bodies of knowledge, and knowledge management is considered an increasingly important source of competitive advantage for organizations. This article applies the knowledge-based view of the firm that has established itself as an important perspective in strategic management. This perspective builds on the resource-based theory of the firm. According to the resource-based theory of the firm, performance differences across firms can be attributed to the variance in the firms' resources and capabilities.

The knowledge-based view argues that the products and services produced by tangible resources depend on how they are combined and applied, which is a function of the firm's "know how." This knowledge is embedded in and carried through individual employees, as well as entities such as organization culture and identity, routines, policies, systems, and documents. The knowledge-based view of the firm posits that these knowledge assets may produce long-term sustainable competitive advantage for the firm, because knowledge-based resources are socially complex to understand and therefore difficult to imitate by other firms (Alavi and Leidner, 2001).

Can knowledge be stored in computers as well as in the human brain? According to Fahey and Prusak (1998), knowledge is what a knower knows; there is no knowledge without someone knowing it. Knowledge is information combined with experience, context, interpretation, reflection, intuition, and creativity. Information, which can be stored in computers, becomes knowledge once it is processed in the mind of an individual. This knowledge then becomes information again once it is articulated or communicated to others in the form of text, computer output, spoken, or written words or other means. Six characteristics of knowledge can distinguish it from information: knowledge is a human act, knowledge is the residue of thinking, knowledge is created in the present moment, knowledge belongs to communities, knowledge circulates through communities in many ways, and new knowledge is created at the boundaries of old.

Our concern with distinctions between information and knowledge is based on real differences as well as technology implications. Information technology implications are concerned with the argument that computers can only manipulate electronic information, not electronic knowledge. Business systems are loaded with information, but without knowledge.

Knowledge management was introduced to the business world to help companies create, share, and use knowledge more effectively. Knowledge management (KM) can be 
defined as a method to simplify and improve the process of sharing, distributing, creating, capturing, and understanding knowledge in the company. KM is description, organization, sharing and development of knowledge in the firm. KM is managing knowledge-intensive activities in the firm. $\mathrm{KM}$ is a discipline focused on systematic and innovative methods, practices, and tools.

Recommendations concerning knowledge management are often far too abstract, and too many questions remain unanswered: What concrete changes in behavior are required? What policies and programs must be in place? How do you get from here to there? (Garvin, 1993). Nonaka (1994) suggested that companies use metaphors and organizational redundancy to focus thinking, encourage dialogue and make tacit, instinctively understood ideas explicit. Garvin (1993) has earlier criticized Nonaka's work for being too abstract. Later, Nonaka et al (2000) have made their ideas more concrete by focusing on the SECI process for knowledge development through socialization, externalization, combination, and internalization.

Several approaches to knowledge management have emerged in the last decade (Gottschalk 2002):

- Managing knowledge workers (e.g., Hitt et al., 2001)

- Intra- and inter-organizational focus (e.g., Sydow and Windeler, 1998)

- Strategic perspectives (e.g., Hansen, 1999)

- Socio-technical perspective (e.g., Pan and Scarbrough, 1999)

- The seci process (e.g., Nonaka et al., 2000)

- Knowledge management episodes (e.g., Holsapple and Joshi, 2000)

- Knowledge markets (e.g., Davenport and Prusak, 2000)

- Activity theory (e.g., Blackler, 1995)

- Common knowledge focus (e.g., Dixon, 2000)

Distinctions can be made among core, advanced, and innovative knowledge. These knowledge categories indicate different levels of knowledge sophistication. Core knowledge is that minimum scope and level of knowledge for daily operations, while advanced knowledge enables a firm to be competitively viable, and innovative knowledge is the knowledge that enables the firm to lead its industry and competitors. Tiwana (2000) describes the different levels of knowledge sophistication as follows:

- Core knowledge is the basic knowledge required to stay in business. This is the type of knowledge that can create efficiency barriers for entry of new companies, as new competitors are not up to speed in basic business processes. Since core knowledge is present at all existing competitors, the firm must have this knowledge even though it will provide the firm with no advantage that distinguishes it from its competitors. In a law firm, examples of core knowledge include knowledge of the law, knowledge of the courts, knowledge of clients and knowledge of procedures.

- Advanced knowledge is what makes the firm competitively visible and active. Such knowledge allows the firm to differentiate its products and services from that of a competitor through the application of superior knowledge in certain areas. Such knowledge allows the firm to compete head on with its competitors in the same market and for the same set of customers. In a law firm, examples of advanced knowledge include knowledge of law applications, knowledge of important court rulings and knowledge of successful procedural case handling.

- Innovative knowledge allows a firm to lead its entire industry to an extent that clearly differentiates it from competition. Such knowledge allows a firm to change the rules of the game by introducing new business practices. Such knowledge enables a firm to expand its market share by winning new customers and by increasing service levels to existing customers. In a law firm, examples of innovative knowledge include knowledge of standardized repetitive legal cases, knowledge of successful settlements and knowledge of modern information technology to track and store vast amounts of information from various sources.

\section{Law Firm Knowledge}

Classification of knowledge into categories and dimensions may depend on industry. For example, there are likely to be different knowledge categories in a bank compared to a law firm. At the same time, there will be certain generic knowledge categories such as market intelligence and technology understanding in most companies independently of industry. When classifying knowledge in a firm, it is important to do the analysis without the organization chart. If you classify knowledge into technology knowledge, production knowledge, marketing knowledge, and financial knowledge, it may be because the firm according to the organization chart consists of a development department, production department, marketing department and financial department. It might be more useful to intro- 
duce new knowledge categories such as product knowledge, which includes knowledge of development, production, marketing, and finance. By identifying crosssectional knowledge categories and dimensions, solutions for improved knowledge flows in the organization will emerge.

A law firm is a good example. A law firm is organized according to legal disciplines. Some lawyers work in the tax department, while others work in the department for mergers and acquisitions. The types of knowledge involved in the practice of law can be categorized as administrative, declarative, procedural, and analytical knowledge. Edwards and Mahling (1997) describes these categories as follows:

- Administrative knowledge, which includes all the nuts and bolts information about firm operations, such as hourly billing rates for lawyers, client names and matters, staff payroll data, and client invoice data.

- Declarative knowledge which is knowledge of the law, the legal principles contained in statutes, court opinions and other sources of primary legal authority; law students spend most of their law school time acquiring this kind of knowledge.

- Procedural knowledge which involves knowledge of the mechanisms of complying with the law's requirements in a particular situation: how documents are used to transfer an asset from Company A to Company $\mathrm{B}$, or how forms must be filed where to create a new corporation. Declarative knowledge is sometimes labeled know-that and know-what, while procedural knowledge is labeled know-how.

- Analytical knowledge that pertains to the conclusions reached about the course of action a particular client should follow in a particular situation. Analytical knowledge results, in essence, from analyzing declarative knowledge (i.e., substantive law principles) as it applies to a particular fact setting.

Classification of knowledge into categories and dimensions has important limitations. For example, the classification into explicit and tacit knowledge may create static views of knowledge. However, knowledge development and sharing are dynamic processes, and these dynamic processes cause tacit knowledge to become explicit, and explicit knowledge to become tacit over time. Tacit and explicit knowledge depend on each other, and they influence each other. In this perspective, Alavi and Leidner (2001) argue that whether tacit or explicit knowledge is the more valuable may indeed miss the point. The two knowledge categories are not dichotomous states of knowledge, but mutually dependent and reinforcing quali- ties of knowledge: tacit knowledge forms the background necessary for assigning the structure to develop and interpret explicit knowledge.

According to Alavi and Leidner (2001), the linkage of tacit and explicit knowledge suggests that only individuals with a requisite level of shared knowledge are able to exchange knowledge. They suggest the existence of a shared knowledge space that is required in order for individual A to understand individual B's knowledge. The knowledge space is the underlying overlap in knowledge base of A and B. This overlap is typically tacit knowledge. It may be argued that the greater the shared knowledge space, the less the context needed for individuals to share knowledge within the group and, hence, the higher the value of explicit knowledge. For example in a law firm, lawyers in the maritime law department may have a large knowledge space so that even a very limited piece of explicit knowledge can be of great value to the lawyers.

\section{Information Technology}

Information technology can play an important role in successful knowledge management initiatives. However, the concept of coding and transmitting knowledge in organizations is not new: training and employee development programs, organizational policies, routines, procedures, reports, and manuals have served this function for many years. What is new and exciting in the knowledge management area is the potential for using modern information technology (e.g., the Internet, intranets, extranets, browsers, data warehouses, data filters, software agents, expert systems) to support knowledge creation, sharing and exchange in an organization and between organizations. Modern information technology can collect, systematize, structure, store, combine, distribute and present information of value to knowledge workers (Nahapiet and Ghoshal, 1998).

According to Davenport and Prusak (2000), more and more companies have instituted knowledge repositories, supporting such diverse types of knowledge as best practice, lessons learned, product development knowledge, customer knowledge, human resource management knowledge, and methods-based knowledge. Groupware and intranet-based technologies have become standard knowledge infrastructures. A new set of professional job titles - the knowledge manager, the knowledge coordinator, and the knowledge-network facilitator - affirms the widespread legitimacy that knowledge management has earned in the corporate world.

The low cost of computers and networks has created a potential infrastructure for knowledge sharing and opened up important knowledge management opportunities. The computational power as such has little relevance to knowl- 
edge work, but the communication and storage capabilities of networked computers make it an important enabler of effective knowledge work. Through email, groupware, the Internet, and intranets, computers and networks can point to people with knowledge and connect people who need to share knowledge independent of time and place

(Gottschalk, 2002).

\section{Stages of Growth Models}

Over time, business organizations have developed and advanced in their use of IT. In the beginning, there was data processing (DP) and data processing systems. Then there were management information systems (MIS) and strategic information systems (SIS). Organizations in the DP era will improve operational efficiency by automating information-based processes. Organizations in the MIS era will improve management effectiveness by satisfying their information requirements. Organizations in the SIS era will improve competitiveness by changing the nature or conduct of business.

This is sometimes called the EEC model, where organizations move from concerns about efficiency (E) to effectiveness (E) and finally to competitiveness $(\mathrm{C})$. In the DP era, efficiency (E) is about doing things right. In the MIS era, effectiveness (E) is about doing the right things. In the SIS era, competitiveness (C) is about gaining competitive advantage in the market place. Based on the EEC model, we now have a method of distinguishing between three eras of IS/IT growth to describe the current IS/IT situation in a company:

- Era 1. Data processing to achieve efficiency. Here focus is on data, where humans have to interpret data to make information out of it.

- Era 2. Management information systems to achieve effectiveness. Here focus is on information, where access to information is achieved.

- Era 3. Strategic information systems to achieve competitiveness. Here focus is on knowledge, where information is organized to support knowledge work.

The EEC model is only one of many stages of IS/IT growth models. Nolan (1979) introduced a model with six stages, which later has been expanded to nine stages. It has been suggested as a theory of IS/IT development over time in organizations. Nolan's model focuses on the level of IS/IT expenditures.

Nolan's model suggests that organizations slowly start out in the initiation stage. Then a period of rapid spreading of IT use takes place in the contagion stage. After a while, the need for control emerges. Control is followed by integration of different technological solutions. The data management enables a development without rising IS/IT expenditures. Then constant growth will take place as the stage of maturity is reached.

To understand the current IS/IT situation in a specific business organization, IS/IT expenditures can be mapped over time. In some firms there are historical accounting figures available at least for the last decade to draw the curve and to judge what stage in the curve the business is at right now. We can get more help to identify the appropriate stage by looking at specific characteristics of each stage as described in the following.

The level of IS/IT expenditures does not only indicate the stage of IS/IT maturity of an organization. We can also look at the application portfolio, the IS/IT organization, the IS/IT planning and control, and the user awareness to estimate stage of growth of an organization. For example, an organization in the initiation stage will have an application portfolio of functional cost-reduction applications, while an organization in the maturity stage will have an application portfolio of applications integrated to handle information flows.

Nolan's stages of growth were introduced three decades ago. Several revisions have been done to the model. In the 1990 s, three more stages were added to the model to cover recent developments in IS/IT in companies. These stages are labeled functional integration, tailored growth and rapid reaction (Gottschalk, 2002). The nine stages can be divided into three eras; each era consisting of three stages. The first era is called data processing (DP) era, the second is information technology (IT) era, while the third is network (NW) era. 


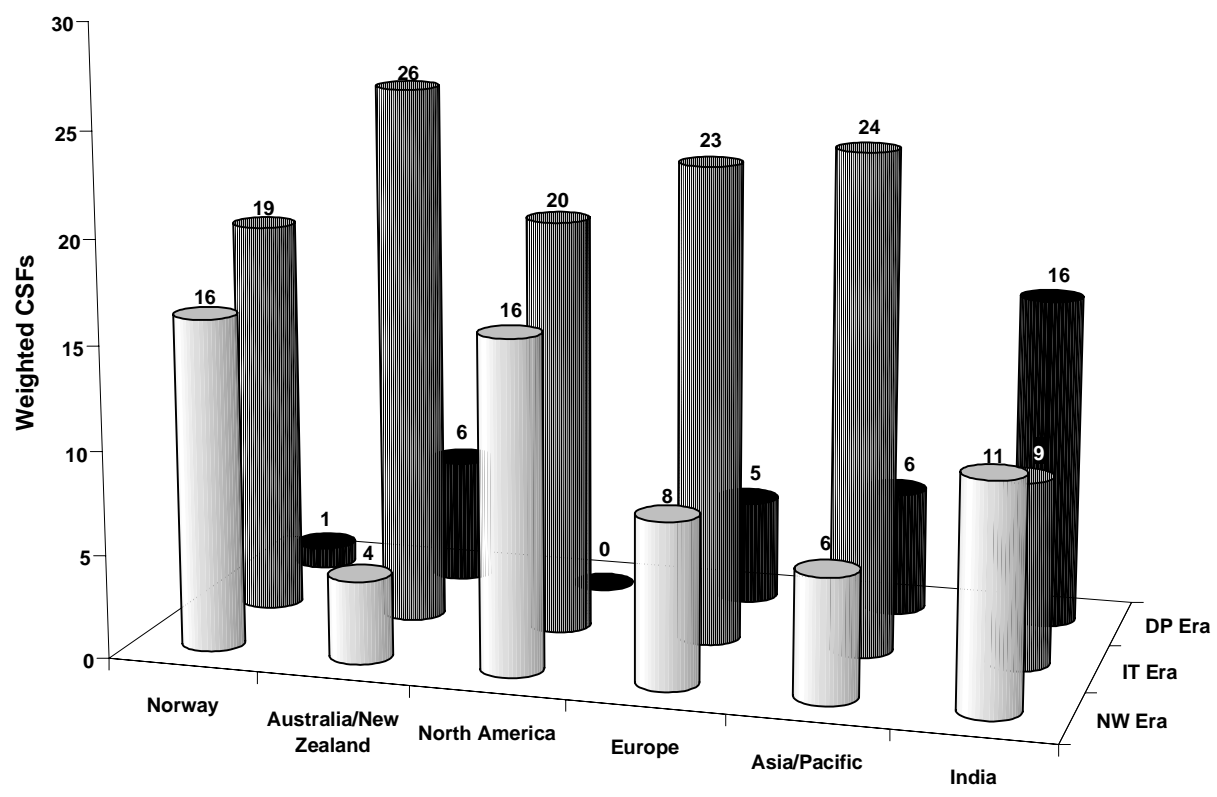

Figure 1. Comparative maturity of IS/IT in various geographic regions

In a study conducted by Gottschalk and Khandelwal (2002), the extent to which business organizations were in these areas, was measured. The approach was through identification of critical success factors (CSF). For example, as illustrated in Figure 1, Norwegian business organizations have left the DP era. Half of them are now in the IT era, while the other half is in the NW area.

Nolan's (1979) stages of growth model is concerned with the general approach to IS/IT in an organization. Other stages of growth models are concerned with specific perspectives or applications of IS/IT.

One example is Earl's (2000) stages of growth model for e-business. For most firms, becoming an e-business is an evolutionary development (Porter, 2001). Earl (2000) has described the typical six-stage journey that corporations are likely to experience. The six stages are not necessarily definitive periods of evolution, as companies may have activities at several neighboring stages at the same time. The six stages can be described as follows (Earl, 2000):

1. External communication. It was more than a decade ago that most corporations wanted a home page on the Internet for the first time. The realization that the Internet was a potential communications channel to external stakeholders, such as investors, analysts, customers, potential recruits, and suppliers, was matched by the recognition that the Web provided an interesting and not too difficult means of designing and publishing corporate public relations material.
The vision behind creating such websites rarely extends beyond external corporate communications. Perhaps the only interactive aspect is a provision for emailed questions to corporate departments from external stakeholders.

2. Internal communication. Intranets, using the Internet and web techniques, are introduced at this stage to raise the information and communication capacity of the organization. An integrated, familiar front end to frequently used internal applications does appeal to end-users. Knowledge management applications have evolved from this stage. And sometimes having internal access to the same information that is provided externally is well received.

Information technology is applied to design consistent and user-friendly front ends to email, groupware, administrative support systems, and other systems used by most people in the organization.

3. E-Commerce. Buying and selling on the Internet take place at this stage. Electronic channels and services are promoted to complement traditional forms of distribution. In the case of start-ups, customers are identified and attracted by using the Web and other advertising channels.

At this stage, organizations struggle with questions such as: What and how do we tell customers and suppliers that they can trade with us online? What pricing policies do we adopt and how do they relate to pricing 
in our traditional channels? Which products and services are suited to electronic market trading? What IS/IT applications and functions are needed to support e-commerce?

4. E-business. Many companies discover a critical lesson at the e-commerce stage. Building an online channel on top of inadequate or inefficient business processes achieves only one thing: it broadcasts and magnifies the fact that the company's backoffice systems or operational processes are really bad. So this fourth stage is about re-engineering and redesigning business processes to match customers' expectations.

Customers already recognize the signs of business processes that are not synchronized with the demands and expectations of e-commerce: goods that do not arrive on time; emailed requests that do not receive response; clumsy handling of returns; inability to track order status; network access that breaks down; and telephone requests where persons answering the phone have no idea what you are talking about.

Most firms learn the hard way and treat stage 3 as inevitable, evolutionary, experiential learning. Then they accept the costs of stage 4, where reengineering of business processes and redesign of architecture and infrastructure of their technology base have to be implemented. The lesson at stage 4 is that highperformance processes are needed to stay in ebusiness.

5. E-Enterprise. Web-enabled online business puts new pressures on management processes. Decision-making occurs increasingly on the network, rather than in meeting rooms. Transactions can be monitored and analyzed in real time. Information can be collected online. New ways of representing and analyzing these data are being developed. We are witnessing new ways of communicating across the enterprise using wireless and mobile technologies.

Wireless and mobile technologies are about to change Internet business. This is being driven by customer demand for wireless devices and the desire to be connected to information and services available through the Internet from anywhere and at any time. Similarly, company employees see no reason anymore for showing up in the office at eight o'clock and leaving again at five. Resulting, telecommunications, the Internet and mobile computing are merging their technologies to form the basis for mobile work and management.

In stage 5, decision-making is becoming entrepreneurial and about communicating decisions across the enterprise. This stage is the dawn of cybernetic models of management where traditional top managers find the time to leave the company. The critical success factor is to recruit, develop and empower people who have the skills to use information and act on it.

6. Transformation. The company has successfully made the journey of e-business. The challenges of the previous stages have been met, and the new business and management solutions required for the e-enterprise are embedded. In many ways, this is the goal. However, we know that nothing stabilize, market forces and emerging technologies drive continuous change.

\section{The KMT Stage Model}

To understand how information technology can support knowledge management in organizations, a model of growth stages is proposed in the following. The purpose of this model is both to be able to understand the current situation in a firm in terms of a specific stage as well as to be able to develop strategies to move to a higher stage in the future.

The first stage is general IT support for knowledge workers. This includes word processing, spreadsheets, and email. The second stage is information about knowledge sources. An information system stores information on who knows what in the firm and outside the firm. The system does not store what they actually know. A typical example is the company intranet. The third stage is information representing knowledge. The system stores what knowledge workers know in terms of information. A typical example is databases such as Lotus Notes bases. The final stage is information processing. An information system uses information to simulate expert opinions. A typical example is expert systems such as Knowledger. The contingent approach implies that the first stage may be right for one firm, while the fourth stage may be right for another firm. Some firms will develop over time, from the first stage to higher stages.

Stages of IT support in knowledge management are useful to identify the current situation as well as plan for future applications in the firm. Let us look more closely at each stage in Figure 2: 


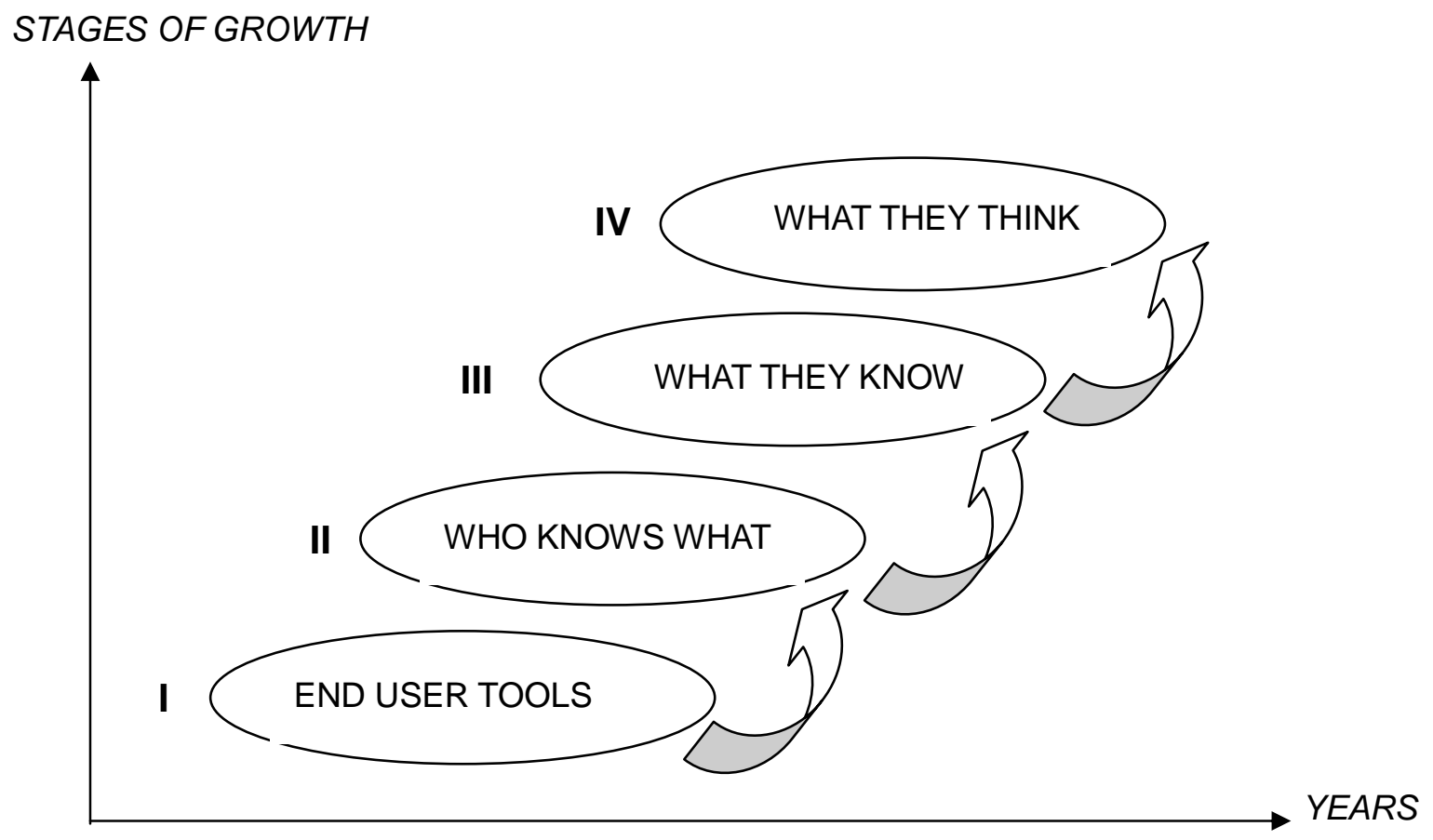

Figure 2. The Knowledge Management Technology (KMT) Stage Model

I. End-user tools are made available to knowledge workers. At the simplest stage, this means a capable networked PC on every desk or in every briefcase, with standardized personal productivity tools (word processing, presentation software) so that documents can be exchanged easily throughout a company. More complex and functional desktop infrastructures can also be the basis for the same types of knowledge support. Stage I is recognized by widespread dissemination and use of end-user tools among knowledge workers in the company. For example, lawyers in a law firm will at this stage use word processing, spreadsheet, legal databases, presentation software, and scheduling programs.

II. Information about who knows what is made available to all people in the firm and to selected outside partners. Search engines should enable work with a thesaurus, since the terminology in which expertise is sought may not always match the terms the expert uses to classify that expertise.

Here we find the cartographic school of knowledge management (Earl 2001), which is concerned with mapping organizational knowledge. It aims to record and disclose who in the organization knows what by building knowledge directories. Often called 'yellow pages,'-, the principal idea is to make sure knowledgeable people in the organization are accessible to others for advice, consultation, or knowledge exchange. Knowledge-oriented directories are not so much repositories of knowledge-based information as gateways to knowledge, and the knowledge is as likely to be tacit as explicit.

One starting approach at Stage II is to store curriculum vitae $(\mathrm{CV})$ for each knowledge worker in the firm. Areas of expertise, projects completed and clients helped may over time expand the CV. For example, a lawyer in a law firm works on cases for clients using different information sources that can be registered on yellow pages in terms of an intranet.

III. Information from knowledge workers is stored and made available to all people in the firm and to selected outside partners. Here data mining techniques can be applied to find relevant information and combine information in data warehouses. On a broader basis, search engines are web browsers and server software that work with a thesaurus, since the terminology in which expertise is sought may not always match the terms the expert uses to classify that expertise.

One starting approach at Stage III is to store project reports, notes, recommendations and letters from each knowledge worker in the firm. Over time, this material will grow fast, making it necessary for a librarian or a chief knowledge officer 
(CKO) to organize it. In a law firm, all client cases will be classified and stored in databases using software such as Lotus Notes.

IV. Information systems solving knowledge problems are made available to knowledge workers and solution seekers. Artificial intelligence is applied in these systems. For example, neural networks are statistically oriented tools that excel at using data to classify cases into one category or another. Another example is expert systems that can enable the knowledge of one or a few experts to be used by a much broader group of workers who need the knowledge.

Expert system is an example of knowledge management technology at Stage IV. According to Curtis and Cobham (2002), the short answer is that an expert system is a computerized system that performs the role of an expert or carries out a task that requires expertise. In order to understand what an expert system is, then, it is worth paying attention to the role of an expert and the nature of expertise. It is then important to ascertain what types of expert and expertise there are in business and what benefits will accrue to an organization when it develops an expert system.

For example, the doctor having a knowledge of diseases comes to a diagnosis of an illness by reasoning from information given by the patient's symptoms and then prescribes medication on the basis of known characteristics of available drugs together with the patient's history. The lawyer advises the client on the likely outcome of litigation based on the facts of the particular case, an expert understanding of the law and knowledge of the way the courts work and interpret this law in practice. The accountant looks at various characteristics of a company's performance and makes a judgment as to the likely state of health of that company (Curtis and Cobham, 2002).

All of these tasks involve some of the features for which computers traditionally have been noted - performing text and numeric processing quickly and efficiently - but they also involve one more ability: reasoning. Reasoning is the movement from details of a particular case and knowledge of the general subject area surrounding that case to the derivation of conclusions. Expert systems incorporate this reasoning by applying general rules in an information base to aspects of a particular case under consideration (Curtis and Cobham, 2002).

When companies want to use knowledge in real-time, mission-critical applications, they have to structure the information base for rapid, precise access. A web search yielding hundreds of documents will not suffice when a customer is waiting on the phone for an answer. Representing and structuring knowledge is a requirement that has long been addressed by artificial intelligence researchers in the form of expert systems and other applications. Now their technologies are being applied in the context of knowledge management. Rule-based systems and case-based systems are used to capture and provide access to customer service problem resolution, legal knowledge, new product development knowledge, and many other types. Although it can be difficult and labor-intensive to author a structured knowledge base, the effort can pay off in terms of faster responses to customers, lower cost per knowledge transaction, and lessened requirements for experienced, expert personnel (Grover and Davenport, 2001).

\begin{tabular}{|c|c|c|c|c|}
\hline LEVELS & $\begin{array}{l}\text { I } \\
\text { END-USER } \\
\text { TOOLS }\end{array}$ & $\begin{array}{c}\text { II } \\
\text { WHO KNOWS } \\
\text { WHAT }\end{array}$ & $\begin{array}{l}\text { III } \\
\text { WHAT THEY } \\
\text { KNOW }\end{array}$ & $\begin{array}{l}\text { IV } \\
\text { WHAT THEY } \\
\text { THINK }\end{array}$ \\
\hline $\begin{array}{l}\text { Distribute } \\
\text { Knowledge }\end{array}$ & $\begin{array}{c}\text { Word Processing } \\
\text { Desktop Publishing } \\
\text { Web Publishing } \\
\text { Electronic Calen- } \\
\text { dars } \\
\text { Presentations }\end{array}$ & $\begin{array}{c}\text { Word Processing } \\
\text { Desktop Publishing } \\
\text { Web Publishing } \\
\text { Electronic Calen- } \\
\text { dars } \\
\text { Presentations }\end{array}$ & $\begin{array}{c}\text { Word Processing } \\
\text { Desktop Publishing } \\
\text { Web Publishing } \\
\text { Electronic Calen- } \\
\text { dars } \\
\text { Presentations }\end{array}$ & $\begin{array}{c}\text { Word Processing } \\
\text { Desktop Publishing } \\
\text { Web Publishing } \\
\text { Electronic Calen- } \\
\text { dars } \\
\text { Presentations }\end{array}$ \\
\hline $\begin{array}{l}\text { Share } \\
\text { Knowledge }\end{array}$ & & $\begin{array}{c}\text { Groupware } \\
\text { Intranets } \\
\text { Networks } \\
\text { E-mail }\end{array}$ & $\begin{array}{c}\text { Groupware } \\
\text { Intranets } \\
\text { Networks } \\
\text { E-mail }\end{array}$ & $\begin{array}{c}\text { Groupware } \\
\text { Intranets } \\
\text { Networks } \\
\text { E-mail }\end{array}$ \\
\hline $\begin{array}{l}\text { Capture } \\
\text { Knowledge }\end{array}$ & & & $\begin{array}{c}\text { Databases } \\
\text { Data Warehouses }\end{array}$ & $\begin{array}{c}\text { Databases } \\
\text { Data Warehouses }\end{array}$ \\
\hline $\begin{array}{l}\text { Apply } \\
\text { Knowledge }\end{array}$ & & & & $\begin{array}{c}\text { Expert systems } \\
\text { Neural networks } \\
\text { Intelligent agents }\end{array}$ \\
\hline
\end{tabular}

Table 1. Examples of IS/IT at different knowledge management stages 


\begin{tabular}{|l|l|l|l|}
\hline \multicolumn{1}{|c|}{ Levels } & \multicolumn{1}{c|}{$\begin{array}{c}\text { Core } \\
\text { Knowledge }\end{array}$} & $\begin{array}{c}\text { Advanced } \\
\text { Knowledge }\end{array}$ & $\begin{array}{c}\text { Innovative } \\
\text { Knowledge }\end{array}$ \\
\hline $\begin{array}{l}\text { Administrative } \\
\text { Knowledge }\end{array}$ & & & \\
\hline $\begin{array}{l}\text { Declarative } \\
\text { Knowledge }\end{array}$ & & & \\
\hline $\begin{array}{l}\text { Procedural } \\
\text { Knowledge }\end{array}$ & & & \\
\hline $\begin{array}{l}\text { Analytical } \\
\text { Knowledge }\end{array}$ & & & \\
\hline
\end{tabular}

Table 2 Knowledge management matrix

Expert systems are at Stage IV. Stewart (1997) argues for Stage II by stating that knowledge grows so fast that any attempt to codify it all is ridiculous; but the identities of in-house experts change slowly. Corporate yellow pages should be so easy to construct, but it's remarkable how few companies have done it. A simple system that connects inquirers to experts save time, reduces error and guesswork, and prevents the reinvention of countless wheels.

What could be stored at Stage III, according to Stewart (1997), are lessons learned and competitor intelligence. A key way to improve knowledge management is to bank lessons learned - in effect, checklists of what went right and wrong, together with guidelines for others undertaking similar projects. In the area of competitor intelligence, companies need to organize knowledge about their suppliers, customers, and competitors.

The KMT growth model states that information technology can be applied at four different levels to support knowledge management in an organization. At the first level, end-user tools are made available to knowledge workers. At the second level, information on who knows what is made available electronically. At the third level, some information representing knowledge is stored and made available electronically. At the fourth level, information systems capable of simulating human thinking are applied in the organization. These four levels are illustrated in Table 1, where they are combined with knowledge management tasks. The entries in the table only serve as examples of current systems.

\section{Application of the KMT Growth Model to Law Firms}

We have introduced law firm knowledge categories of administrative knowledge, declarative knowledge, procedural knowledge and analytical knowledge. Furthermore, we have made distinctions between core knowledge, advanced knowledge and innovative knowledge. These two sets of knowledge classification can be combined. For example, a law firm can have core procedural knowledge, advanced procedural knowledge and innovative procedural knowledge as illustrated in Table 2. This is called the knowledge management matrix.

The knowledge management matrix can first be used to identify the current IS/IT that support knowledge management in the firm as illustrated in Table 3. 


\begin{tabular}{|l|c|c|c|}
\hline \multicolumn{1}{|c|}{ Levels } & $\begin{array}{c}\text { Core } \\
\text { Knowledge }\end{array}$ & $\begin{array}{c}\text { Advanced } \\
\text { Knowledge }\end{array}$ & $\begin{array}{c}\text { Innovative } \\
\text { Knowledge }\end{array}$ \\
\hline Administrative & $\begin{array}{c}\text { Accounting system } \\
\text { Hours billing } \\
\text { Clients database } \\
\text { E-mail } \\
\text { Kord processing } \\
\text { Spreadsheet } \\
\text { Salary system }\end{array}$ & $\begin{array}{c}\text { Competence database } \\
\text { Client firm information } \\
\text { Internet }\end{array}$ & \\
\hline Declarative & $\begin{array}{c}\text { Library system } \\
\text { Electronic law-book } \\
\text { Electronic legal sources }\end{array}$ & Law database & \\
\hline Knowledge & $\begin{array}{c}\text { Case collection } \\
\text { Kocument standards } \\
\text { Procedural standards } \\
\text { Document examples }\end{array}$ & Internal databases & Intranet \\
\hline Knowledic databases & \\
\hline Analytical & Law interpretations & Groupware & \\
\hline
\end{tabular}

Table 3 Knowledge management matrix for the current IS/IT situation

\begin{tabular}{|c|c|c|c|}
\hline $\begin{array}{l}\text { Levels } \\
\text { Categories }\end{array}$ & $\begin{array}{c}\text { Core } \\
\text { Knowledge }\end{array}$ & $\begin{array}{c}\text { Advanced } \\
\text { Knowledge }\end{array}$ & $\begin{array}{l}\text { Innovative } \\
\text { Knowledge }\end{array}$ \\
\hline $\begin{array}{l}\text { Administrative } \\
\text { Knowledge }\end{array}$ & $\begin{array}{c}\text { Accounting system } \\
\text { Hours billing } \\
\text { Clients database } \\
\text { E-mail } \\
\text { Word processing } \\
\text { Spreadsheet } \\
\text { Salary system } \\
\text { Electronic diary } \\
\text { Electronic reception } \\
\text { Office automation } \\
\text { Message system }\end{array}$ & $\begin{array}{c}\text { Competence database } \\
\text { Client firm information } \\
\text { Internet } \\
\text { Videophone } \\
\text { Video conference } \\
\text { Quality system } \\
\text { Financial services } \\
\text { Intranet } \\
\text { Net agent } \\
\text { Electronic meetings }\end{array}$ & $\begin{array}{c}\text { Client statistics } \\
\text { Lawyer statistics } \\
\text { Recruiting system } \\
\text { Scanning } \\
\text { Quality assurance } \\
\text { Benchmarking } \\
\text { Customer relationships } \\
\text { Net-based services } \\
\text { Electronic diary } \\
\text { Mobile office } \\
\text { Executive information }\end{array}$ \\
\hline $\begin{array}{l}\text { Declarative } \\
\text { Knowledge }\end{array}$ & $\begin{array}{c}\text { Library system } \\
\text { Electronic law-book } \\
\text { Electronic legal sources } \\
\text { Document management } \\
\text { Legal databases } \\
\text { Commercial databases }\end{array}$ & $\begin{array}{c}\text { Law database } \\
\text { Electronic library } \\
\text { Electronic law-book } \\
\text { Extranet } \\
\text { International legal sources }\end{array}$ & $\begin{array}{c}\text { Law change base } \\
\text { Precedence base } \\
\text { Conference system } \\
\text { Intelligent agents } \\
\text { Artificial intelligence } \\
\text { Portals } \\
\text { Work flow systems }\end{array}$ \\
\hline $\begin{array}{l}\text { Procedural } \\
\text { Knowledge }\end{array}$ & $\begin{array}{c}\text { Case collection } \\
\text { Document standards } \\
\text { Procedural standards } \\
\text { Document examples } \\
\text { Planning system } \\
\text { Standards archive } \\
\text { Publishing system }\end{array}$ & $\begin{array}{c}\text { Internal databases } \\
\text { Intranet } \\
\text { Public databases } \\
\text { Experience database } \\
\text { Image processing } \\
\text { Document generation } \\
\text { International law base } \\
\text { Public web access } \\
\end{array}$ & $\begin{array}{l}\text { Video registration } \\
\text { Case system } \\
\text { Online services }\end{array}$ \\
\hline $\begin{array}{l}\text { Analytical } \\
\text { Knowledge }\end{array}$ & $\begin{array}{l}\text { Law interpretations } \\
\text { Voice recognition } \\
\text { Case interpretations }\end{array}$ & $\begin{array}{c}\text { Groupware } \\
\text { Intelligent agents } \\
\text { Client monitoring } \\
\text { Extranet } \\
\text { Discussion groups } \\
\text { Video conference }\end{array}$ & $\begin{array}{c}\text { Expert register } \\
\text { Expert system } \\
\text { Research reports } \\
\text { Subject database } \\
\text { Data warehouse }\end{array}$ \\
\hline
\end{tabular}

Table 4 Knowledge management matrix for desired IS/IT situation 
Now the knowledge management matrix can be applied to identify future IS/IT as illustrated in Table 4 . The systems do only serve as examples' they illustrate that it is possible to find systems than can support all combinations of knowledge categories and knowledge levels. This table illustrates both current and future applications of information systems and information technology, enabling a diagnosis of both current and future stage of growth for knowledge management technology in a law firm. The current systems are written in normal fonts, while future systems are written in cursive.

Software and systems suitable for knowledge management in a law firm can now be identified using the knowledge management matrix. In Table 5, examples of software to support systems in Table 4 are listed.

One example in Table 5 is Knowledger, which is listed as a potential software in the innovative-analytical knowledge location. This is an ambitious location of a software product that has yet to demonstrate its real capabilities in knowledge firms. According to the vendor Knowledge Associates, Knowledger 3.0 is a complete knowledge management software that can be integrated with other systems in the firm. Knowledger is web-based and supports the firm in categorizing internal and external infor-

\begin{tabular}{|c|c|c|c|}
\hline $\begin{array}{l}\text { Levels } \\
\text { Categories }\end{array}$ & $\begin{array}{c}\text { Core } \\
\text { Knowledge }\end{array}$ & $\begin{array}{c}\text { Advanced } \\
\text { Knowledge }\end{array}$ & $\begin{array}{l}\text { Innovative } \\
\text { Knowledge }\end{array}$ \\
\hline $\begin{array}{l}\text { Administrative } \\
\text { Knowledge }\end{array}$ & $\begin{array}{c}\text { Microsoft Word } \\
\text { Microsoft Excel } \\
\text { Microsoft Outlook } \\
\text { SuperOffice } \\
\text { Timex } \\
\text { Concorde XAL } \\
\text { DBMS } \\
\text { SuperOffice } \\
\text { Microsoft Office } \\
\text { Oracle } \\
\text { Agresso } \\
\text { Powermarkt } \\
\text { Uni økonomi } \\
\text { Datalex } \\
\text { Justice Data Systems } \\
\text { GroupWise } \\
\text { Alta Law Office } \\
\text { ESI Law }\end{array}$ & $\begin{array}{c}\text { Microsoft Access } \\
\text { Lotus Approach } \\
\text { Corel Paradox } \\
\text { Infotorg } \\
\text { IFS } \\
\text { Rubicon } \\
\text { Concorde } \\
\text { K-link } \\
\text { Akelius dokument } \\
\text { Windows NT } \\
\text { Explorer } \\
\text { CheckPoint Firewall } \\
\text { RealMedia } \\
\text { Advisor klient } \\
\text { Completo Advokat } \\
\text { Visma Business Advokat }\end{array}$ & $\begin{array}{c}\text { Intranett } \\
\text { Internet } \\
\text { Ekstranett } \\
\text { WAP } \\
\text { PDA/Palm } \\
\text { KnowledgeShare } \\
\text { IFS Business performance } \\
\text { Mikromarc } 2 \text { statistikk } \\
\text { IFS Front Office } \\
\text { Psion } \\
\text { Nomade } \\
\text { Netscape Netcaster }\end{array}$ \\
\hline $\begin{array}{l}\text { Declarative } \\
\text { Knowledge }\end{array}$ & $\begin{array}{l}\text { NorLex } \\
\text { CarNov } \\
\text { RightOn } \\
\text { Lovdata } \\
\text { NORSOK }\end{array}$ & $\begin{array}{c}\text { Lovdata } \\
\text { Celex } \\
\text { BibJure } \\
\text { Shyster } \\
\text { Finder } \\
\text { Prjus } \\
\text { BookWhere }\end{array}$ & $\begin{array}{l}\text { Hieros Gamos } \\
\text { Eudor } \\
\text { Abacus Law } \\
\text { Lawgic } \\
\text { Netmeeting } \\
\text { Lov chat } \\
\text { LegalSeeker } \\
\text { KG Agent } \\
\text { Lotus K-station } \\
\text { Domino Workflow }\end{array}$ \\
\hline $\begin{array}{l}\text { Procedural } \\
\text { Knowledge }\end{array}$ & $\begin{array}{c}\text { Jasper } \\
\text { Karnov } \\
\text { Mikas } \\
\text { Aladdin ePaper } \\
\text { Action Request System } \\
\text { DocuShare } \\
\text { CyberWorks Training } \\
\text { Learning Space }\end{array}$ & $\begin{array}{c}\text { Lotus Domino } \\
\text { Domino.Doc } \\
\text { DOCS Open } \\
\text { HotDocs } \\
\text { Adobe photoshop } \\
\text { EUR-Lex } \\
\text { ODIN } \\
\text { eCabinet }\end{array}$ & $\begin{array}{c}\text { Justice } \\
\text { Autonomy } \\
\text { LegalSeeker } \\
\text { Expert Legal Systems } \\
\text { Hieros Gamos } \\
\text { Real Media } \\
\text { Amicus Attorney }\end{array}$ \\
\hline $\begin{array}{l}\text { Analytical } \\
\text { Knowledge }\end{array}$ & $\begin{array}{c}\text { PDA/Palm } \\
\text { Lotus LearningSpace } \\
\text { Lotus Quickplace } \\
\text { Lotus Sametime } \\
\text { IBM Content Manager } \\
\text { IBM Enterprise Portal } \\
\text { Voice Express } \\
\text { Collaborative Virtual Work } \\
\text { Search Sugar } \\
\text { Vchip }\end{array}$ & $\begin{array}{c}\text { Lotus Notes } \\
\text { iNotes } \\
\text { Lotus K-Station } \\
\text { Jasper } \\
\text { Novell GroupWise } \\
\text { Microsoft Exchange } \\
\text { Netscape Communicator } \\
\text { JSF Litigator's Notebook } \\
\text { Empolis K42 } \\
\text { Legal Files }\end{array}$ & $\begin{array}{c}\text { Summation } \\
\text { Knowledger } \\
\text { Lotus Raven } \\
\text { Shyster } \\
\text { XpertRule Miner } \\
\text { Expert Choice } \\
\text { Dragon Dictate }\end{array}$ \\
\hline
\end{tabular}

Table 5 Knowledge management matrix for software supporting desired IS/IT situation 
mation, as well as linking incoming information to existing information.

Another noteworthy application in the most demanding location of innovative-analytical knowledge is called Summation. Summation is a system for document handling for use in large court cases. In the large court case of Balder in Norway, law firm Thommessen Krefting Greve Lund (TKGL) used Summation in 2001. The Balder case is a dispute between Exxon and Smedvig about the rebuilding of an offshore vessel costing 3 billion Norwegian kroner. TKGL had more than 2500 binders when the court case started in the city of Stavanger. All these documents were scanned into a database for use by Summation. When lawyers from TKGL present material in court, they submit it from their laptops. When new information emerges in court, then it is registered in Summation. When TKGL lawyers are to trace technical and financial developments for Balder, they make a search in the Summation database.

Another law firm is also using Summation. The law firm Bugge Arentz-Hansen Rasmussen (BA-HR) has the task of finding money after the late ship-owner Jahre. The money is expected to be found in banks in countries where there are no taxes. The hunt for Jahre funds has been going on for almost a decade, and BA-HR has developed a large Summation database enabling BA-HR lawyers to present important information in the court in the city of Drammen.

A third example of Summation use can be found in the US. The Justice Department used Summation in its legal struggle with Microsoft. According to Summation Legal Technologies, Summation helped the Justice's lead prosecutor, David Boies; piece together the most damaging information for Microsoft. In presenting its defense, which ended on February 26, Microsoft relied more than Justice did on a low-tech overhead projector.

According to Susskind (2000, p. 163), six kinds of expert systems can play an important role in law firms in the future:

- Diagnostic systems. Those systems offer specific solutions to problems presented to them. From the facts of any particular case, as elicited by such a system, it will analyze the details and draw conclusions, usually after some kind of interactive consultation. These systems are analogous to the medical diagnostic systems that make diagnoses on the basis of symptoms presented to them. An example of a diagnostic system in law would be a taxation system that could pinpoint the extent to which and why a person is liable to pay tax, doing so on the basis of a mass of details provided to it.

- Planning systems. In a sense, planning systems reason in reverse. For these systems are instructed as to a de- sired solution or outcome and their purpose is to identify scenarios, involving both factual and legal premises, which justify the preferred conclusion. In tax law, a planning system could recommend how best a taxpayer should arrange his affairs so as to minimize his exposure to liability. The knowledge held within planning systems can be very similar to that held within diagnostic systems; what is quite different is the way that that knowledge is applied.

- Procedural guides. Many complex tasks facing legal professionals require extensive expertise and knowledge that is in fact procedural in nature. Expert systems as procedural guides take their users through such complex and extended procedures, ensuring that all matters are attended to and done within any prescribed time periods. An example of such a system would be one that managed the flow of a complex tax evasion case, providing detailed guidance and support from inception through to final disposal.

- The intelligent checklist. This category of system has most often been used to assist in auditing or reviewing compliance with legal regulations. Compliance reviews must be undertaken with relentless attention to detail and extensive reference to large bodies of regulations. Intelligent checklists provide a technique for performing such reviews. They formalize the process. In taxation, an intelligent checklist approach could be used to assist in the review of a company's compliance with corporation tax.

- Document modeling systems. These systems - also referred to as document assembly systems - store templates set up by legal experts. These templates contain fixed portions of text together with precise indications as to the conditions under which given extracts should be used. In operation, such a system will elicit from its user all the details relevant to a proposed document. The user answering questions, responding to prompts and providing information does this. On the basis of the user's input, the system will automatically generate a customized and polished document on the basis of its knowledge of how its text should be used.

- Arguments generation systems. It is envisaged that these systems are able to generate sets of competing legal arguments, in situations when legal resources do not provide definitive guidance. Rather than seeking to provide legal solutions (as diagnostic systems strive to do), argument generation systems will present sound lines of reasoning, backed both by legal authority and by propositions of principle and policy. These lines of reasoning will lead to a range of legal conclusions. Such systems would help users identify promising lines of reasoning in support of desired outcomes 
while, at the same time, advancing other arguments which may need to be refuted. tion technology may be an enabler of knowledge management improvement in law firms.

\begin{tabular}{|l|c|c|c|}
\hline \multicolumn{1}{|c|}{ Levels } & $\begin{array}{c}\text { Core } \\
\text { Knowledge }\end{array}$ & $\begin{array}{c}\text { Advanced } \\
\text { Knowledge }\end{array}$ & $\begin{array}{c}\text { Innovative } \\
\text { Knowledge }\end{array}$ \\
\hline $\begin{array}{l}\text { Administrative } \\
\text { Knowledge }\end{array}$ & I & I & II \\
\hline $\begin{array}{l}\text { Declarative } \\
\text { Knowledge }\end{array}$ & I & I & II \\
\hline $\begin{array}{l}\text { Procedural } \\
\text { Knowledge }\end{array}$ & III & III & IV \\
\hline $\begin{array}{l}\text { Analytical } \\
\text { Knowledge }\end{array}$ & I & III & IV \\
\hline
\end{tabular}

Table 6 Knowledge management matrix applied to stages of growth.

We now return to the KMT growth model. By combining the knowledge management matrix for law firms with the stages of growth model, a KMT growth model for law firms can be developed as illustrated in Table 6 .

IT for administrative core and advanced knowledge as well as IT for declarative core and advanced knowledge is mainly end-user tools at Stage I. IT for administrative and declarative innovative knowledge is mainly for who knows what at Stage II. IT for advanced analytical knowledge is mainly for what they know at Stage III, while IT for innovative analytical knowledge is mainly for what they think at Stage IV.

The classification of each of the twelve matrix elements in Table 6 can be challenged. The main framework, however, should be agreeable. The main idea says that when a law firm moves from the upper-left corner in the knowledge management matrix to the lower-right corner in the matrix, then the firm evolves through stages of growth in the use of knowledge management technology.

\section{Conclusion}

A stages of growth model is proposed to understand the stage at which at law firm is found concerning applications of information technology in knowledge management. Four stages are defined, and a law firm can use the model to develop a strategy for implementing technology at higher stages in the model.

Experts in the field tend to concur that knowledge management can be improved in law firms, and that informa-
Law firms to develop a strategy for implementing technology at higher stages may use the proposed four stages in the Knowledge Management Technology growth model. Furthermore, the application of the KMT growth model may be used to identify the current IS/IT that support knowledge management in law firms.

This paper has presented a model. Future research will show whether this model has value. Future research will take three directions. First, categorization of stages and other theoretical issues may be further developed. Second, empirical testing of the model will indicate to what extent it is possible to assign existing law firms to different KMT growth stages. Finally, the model will be adapted to other types of organizations.

\section{References}

Alavi, M. and Leidner, D.E. (2001). Knowledge Management and Knowledge Management Systems: Conceptual Foundations and Research Issues. MIS Quarterly, 25 (1), 107-136.

Becker, W.M.; Herman, M.F.; Samuelson, P.A. and Webb, A.P. (2001). Lawyers get down to business. The McKinsey Quarterly, (2), 45-55.

Blackler, F. (1995). Knowledge, Knowledge Work and Organizations: An Overview and Interpretation. Organization Studies, 16 (6), 1021-1046.

Curtis, G. and Cobham, D. (2002). Business Information Systems: Analysis, Design and Practice, UK: Prentice Hall.

Davenport, T.H. and Prusak, L. (2000). Working Knowledge, USA: Harvard Business School Press. 
Dixon, N.M. (2000), Common Knowledge, USA: Harvard Business School Press.

Earl, M.J. (2000). Evolving the E-business. Business Strategy Review, 11 (2), 33-38.

Earl, M.J. (2001). Knowledge Management Strategies: Toward a Taxonomy. Journal of Management Information Systems, 18 (1), 215-233.

Edwards, D.L. and Mahling, D.E. (1997). Toward Knowledge Management Systems in the Legal Domain. Proceedings of the International ACM SIGGROUP Conference on Supporting Group Work Group '97, USA: The Association of Computing Machinery ACM, 158-166.

Fahey, L. and Prusak, L. (1998). The Eleven Deadliest Sins of Knowledge Management. California Management Review, Spring, 9-21.

Galanter, M. and Palay, T. (1991). Tournament of Lawyers, The Transformation of the Big Law Firm, USA: The University of Chicago Press.

Garvin, D.A. (1993). Building a learning organization, Harvard Business Review, July-August, 78-91.

Gottschalk, P. (2002). Knowledge Management through Information Technology, Bergen, Norway: Fagbokforlaget publishing, www.fagbokforlaget.no.

Gottschalk, P. and Khandelwal, V.K. (2002). Global Comparison of Stages of Growth Based on Critical Success Factors. Journal of Global Information Management, 10 (2), 42-51.

Grover, V. and Davenport, T.H. (2001). General Perspectives on Knowledge Management: Fostering a Research Agenda. Journal of Management Information Systems (JMIS), 18 (1), 5-21.

Hansen, M.T. (1999). The Search-Transfer Problem: The Role of Weak Ties in Sharing Knowledge across Organizational Subunits. Administrative Science Quarterly, 44, 82-111.

Hitt, M.A.; Bierman, L.; Shimizu, K. and Kochhar, R. (2001). Direct and moderating effects of human capital on strategy and performance in professional service firms: a resource-based perspective. Academy of Management Journal, 44 (1), 13-28.

Holsapple, C.W. and Joshi, K.D. (2000). An investigation of factors that influence the management of knowledge in organizations. Journal of Strategic Information Systems, 9, 235-261.

Montana, J.C. (2000). The Legal System and Knowledge Management, The Information Management Journal, July, 54-57.

Mountain, D. (2001). Could New Technologies cause Great Law Firms to Fail? Journal of Information, Law \& Technology (JILT), issue 1, 9 pages. <ttp://elj.warwick.ac.uk/jilt/01t/mountain.hmt
Nahapiet, J. and Ghoshal, S. (1998). Social capital, intellectual capital, and the organizational advantage. Academy of Management Review, 23 (2), 242-266.

Nolan, R.L. (1979). Managing the crises in data processing. Harvard Business Review, March-April, 115-126.

Nonaka, I. (1994). A Dynamic Theory of Organizational Knowledge Creation. Organization Science, 5 (1), 14-37.

Nonaka, I.; Toyama, R. and Konno, N. (2000). SECI, Ba and Leadership: a Unified Model of Dynamic Knowledge Creation. Long Range Planning, 33 (1), 5-34.

Pan, S.L. and Scarbrough, H. (1999). Knowledge Management in Practice: An Exploratory Case Study. Technology Analysis \& Strategic Management, 11 (3), 359-374.

Porter, M.E. (2001). Strategy and the Internet, Harvard Business Review, March, 63-78.

Stewart, T.A. (1997). Intellectual Capital: The New Wealth of Organizations, UK: Nicholas Brealy Publishing.

Susskind, R. (2000). Transforming the Law, UK: Oxford University Press.

Sydow, J. and Windeler, A. (1998). Organizing and Evaluating Interfirm Networks: A Structurationist Perspective on Network Processes and Effectiveness. Organization Science, 9 (3), 265284.

Tiwana, A. (2000). The Knowledge Management Toolkit - Practical Techniques for Building a Knowledge Management System, USA: Prentice Hall.

\section{Biography}

Petter Gottschalk is professor of information technology management in the department of leadership and organizational management at the Norwegian School of Management BI. He received his MBA in Germany (Technical University of Berlin), his MSc in the US (Thayer School of Engineering, Dartmouth College) and his DBA in the UK (Henley Management College, Brunel University). Professor Gottschalk has published extensively in international journals such as Information \& Management, Long Range Planning, Journal of Global Information Management and Informing Science. His most recent textbook is Knowledge Management through Information Technology published by Fagbokforlaget (Www.fagbokforlaget.no) His executive experience includes positions such as ClO at ABB, CEO at ABB Datacable and CEO at the Norwegian Computing Center. 